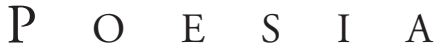

M A G A L I O LIVEIRA FER A D ES

\section{O TERMÔMETRO}

o termômetro marcava quatro graus... fiz um passeio à tarde com meus amigos ao mis para ver uma pequena exposição de capas de livros. assisti no caminho a um espetáculo de miséria: muitos homens e mulheres sem teto passavam frio e fome nas ruas da cidade: capas de livros não ocupavam mais lugar e sentido no desalinho da paisagem dos meus olhos tão embriagados de passividade numa noite que não teve fim... 


\section{P O E S I A}

\section{HOMEM}

no homem me interessa

menos o corpo,

quero dele o que não se

sabe ainda, a outra

parte: o sol saindo das

orelhas-borboletas e

voadoras de um elefante

leve, quente e feliz.

\section{SINS}

amor soa sins

e tateia eus

na gratuidade

do corpo.

é folha de livro

que (lida ou quase)

se desfaz no tempo.

fica somente o perfume,

um outro texto,

submerso

na imensidão do ar. 


\section{P $\quad \mathrm{O} \quad \mathrm{E} \quad \mathrm{S} \quad \mathrm{I} \quad \mathrm{A}$}

\section{FORMA DO VAZIO}

em toneladas de nadas

voo em verso: minha existência

a olho nu. dispenso drogas

nas suas transcendências

sórdidas e sanguessugas.

prefiro

a forma do vazio

soada no limite flexível

da palavra.

\section{MAR}

mar: manto e música

minha miragem

palavra em sopro e espuma

alonga a tua língua azul

epifânica

sobre meu corpo frio

e quase morto.

rima polifônica em sal.

Magali Oliveira Fernandes nasceu em São Paulo. É pesquisadora na área de comunicação - ediçãa. Atualmente, trabalha na Univesp. Tem textos publicados sobre o tema da edição popular no Brasil, entre eles: Chico Xavier - um herói brasileiro no universo da edição popular (2008, Editora Annablume), resultado de seu doutorado defendido na PUC-SP. Em poesia, lançou: Olho nu (2000, Ateliê/Educ/ComArte) e Sins - poemas para não ler (2006, Dix Editorial), dos quais foi extraido o que vai aqui publicado. 